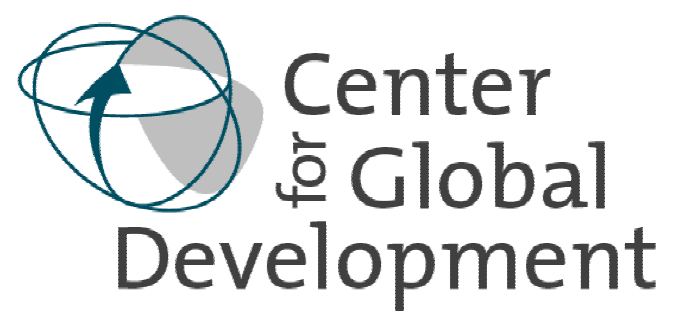

WORKING PAPER NUMBER 13

OC TO B E 2002

Low Investment is not the

Constraint on African

Development

By Shantayanan Devarajan,

William R. Easterly,

Howard Pack

\title{
Abstract
}

While many analysts decry the lack of sufficient investment in Africa, we find no evidence that private and public investment are productive, either in Africa as a whole (unless Botswana is included in the sample), or in the manufacturing sector in Tanzania. In this restricted sense, inadequate investment is not the major obstacle to African economic development. 



\title{
"Low Investment is not the Constraint on African Development",
}

\author{
Shantayanan Devarajan* \\ William R. Easterly** \\ Howard Pack***
}

\section{Center for Global Development}

Working Paper No. 13

October 2002

\footnotetext{
${ }^{1}$ This paper does not necessarily reflect the views of the World Bank or its member countries. We thank Patrick Asea, Benno Ndulu and seminar participants at the World Bank and AERC Biannual Research Workshop for helpful comments and a referee of this journal who provided detailed comments. *World Bank, **New York University and Center for Global Development, *** University of Pennsylvania
} 


\section{Introduction}

Analysts of Sub-Saharan Africa's dismal growth performance over the postindependence period often note that investment was significantly lower in Africa than in other regions during this period. During the years 1960-94 Africa invested 9.6 percent of GDP (measured at international prices), while the ratio for other developing countries was 15.6 percent (Hoeffler [1999]). Inasmuch as Levine and Renelt [1992] identified investment as one of the few robust variables in cross-country growth regressions, economists often conclude that Africa's low investment share was the major, although not the only, source of its disappointing growth performance (Barro and Lee [1993], Collier and Gunning [1997]).

Private investment is endogenous and a few researchers have sought the fundamental (and presumably exogenous) factors in explaining Africa's growth. Among the variables investigated in recent studies have been the proximity to the tropics, ethnic fractionalization and weak social capital (Sachs and Warner [1997], Easterly and Levine [1997], Collier and Gunning [1997]). In an interesting recent paper, Hoeffler [1999] shows that, when the endogeneity of investment and unobserved country-specific effects are allowed for, the so-called "Africa dummy" - the unexplained component of African growth that has frequently been found significant —disappears.

While Africa's total investment rate was below that of other developing countries, public investment rates were about the same in the two sets of countries (about 7 percent of GDP). Any statement about whether African investment was the source of poor performance would therefore have to analyze the composition of that investment - and whether more public investment, an instrument under government control, would have benefited the continent.

In this paper we analyze the productivity of economy-wide investment across countries, and try to obtain some insight into the underlying process generating the aggregate results by a case study of the evolution of the manufacturing sector in Tanzania. We find that low investment has not been the major constraint on development in Africa. In section II, we use cross-country regressions to explore whether public and private investment had a positive and 
significant effect on aggregate growth in Africa. Regardless of the true underlying production function, investment should be positively associated with growth though the precise impact would vary with different functional forms. But we are searching for gross correlations that can be obtained from available data. If a check of the initial screening is positive, we can search for more precise relations.

Recognizing that private investment is endogenous, we use the method of instrumental variables (with the level of private investment at the beginning of the period as the instrument). Our basic finding is that public investment is not correlated with growth in Africa. Private investment is also not correlated with growth unless Botswana is included in the sample. A simple scatter plot of the data shows why: Botswana is the only country in Africa to have experienced high private investment rates and high growth. We provide a brief discussion of the experience of Botswana to justify excluding it from the sample.

Studies of the effect of private investment have shown that it is associated with long-run growth (Levine and Renelt [1992], DeLong and Summers [1991]). ${ }^{2}$ The more general question of the importance of all fixed investment, public and private, in the aggregate growth process is less clear. Young [1995] found that capital accumulation played a major role in the East Asian growth miracles, assigning a relatively minor role to TFP growth. Nelson and Pack [1999] question these results, showing that the contribution of TFP growth and capital accumulation cannot be disentangled in a general production function without specifying the elasticity of substitution and the form of technical progress. Klenow and Rodriguez-Clare [1997] also cast doubt on Young's results by showing that the cross-country variation in TFP growth rates accounts for 92 percent of the cross-country variation in per capita growth. Easterly and Levine 2000 also find that many stylized facts about growth imply that most growth and income differences are explained by the "TFP residual" not by factor accumulation.

The impact of public investment is even more ambiguous. Public spending on roads,

\footnotetext{
${ }^{2}$ Auerbach, et. al., however, show that this result is contingent on the inclusion of Botswana in the sample, an issue that we consider below.
} 
education, and the provision of utilities is generally thought to contribute to growth by providing inputs that are complementary to more directly productive investments such as equipment. But there are no consistent empirical results confirming this association. Easterly and Rebelo [1994] find a positive relationship across all countries between public infrastructure investment and growth (but no effect of total public investment on growth), whereas Devarajan et al. [1997] find that the share of public spending devoted to capital expenditure has a negative association with long-run growth.

Several studies examine whether a similar pattern emerges when the sample is restricted to African countries. Khan and Kumar [1997] find that private investment is more productive than public investment in a global sample as well as one restricted to African countries (i.e., when they use regional slope dummies). Calamitsis et al. [1999] also find that private investment is significant in an African growth regression, while public investment is not robustly significant. These results confirm earlier results by Khan and Reinhart [1990]. In contrast, Hadjimichael et al. [1995] show that public investment has a higher coefficient in a crosscountry growth regression of African countries. Furthermore, they find that the coefficient on private investment is not statistically significant when macroeconomic policy variables are included in the regression. They interpret this result as implying that the only way investment affects growth in Africa is directly through capital accumulation, and not through increased productivity growth. Similarly, in a case study of Kenya, Oshikoya [1992] shows that the only period in which investment had a significant impact on growth was 1980-89, which was the period of financial liberalization. It is interesting to note that almost all of the African samples contain Botswana, and none of them reports the results of excluding Botswana from the sample, an issue we return to below.

Other studies consider the more fundamental question of the determinants of investment in Africa. Most emphasize the role of macroeconomic policies as major influences on African investment rates. For example, Oshikoya [1992, 1994] finds that credit availability and low inflation are the major determinants of investment in Africa. Elbadawi et al. [1998] show the role of instability in lowering Africa's investment rate. In a study of the SADC countries, 
Mlambo and Elhiraika [1997] find that while favorable macroeconomic policies have a positive effect on private investment, public investment does not--implying that there may be some crowding-out in these countries.

Cross-country regressions such as those cited earlier that analyze the effect of many factors on growth rates assume that TFP growth is uniform across all countries (Pack, 1994, Parente and Prescott, 2000). Our results showing the absence of any relation between investment and growth may be attributable to the decline in TFP in countries that have invested more. To investigate this possibility we examine the evolution of one, albeit small sector, manufacturing in Tanzania. For the simple labor-intensive manufacturing sectors typical of most African countries, there is a considerable shelf of international technology that is relatively freely available. Unlike advanced sectors, the technology has often been in use for a quarter century or more and is no longer proprietary, though the efficient domestic absorption of new investment may require substantial local effort. We show that a combination of factors, including public policies, insulation from market forces, and low levels of education acted together to render unproductive the high levels of investment in Tanzania's manufacturing sector. If Tanzania is representative of other African countries, our analysis may explain part of the pattern underlying the cross-country regressions reported in section II, though expansion of such analysis to the rural sector must also be carried out for a more complete understanding of the aggregate performance of these economies.

\section{Cross-country analysis of the effect on growth of public and private_investment in} Africa

In this section we analyze the cross-country evidence on the returns to public and private investment in Africa. ${ }^{3}$ We first examine simple correlations between public investment and growth, and private investment and growth in Africa. Then we present a regression of growth during the years 1970-97 on the averages of public and private investment to GDP, initial

\footnotetext{
${ }^{3}$ This section draws on Dollar and Easterly [1998].
} 
income, and population growth.

\section{A. Cross-section results - growth and investment}

It is necessary to first discuss the sources of data. Total investment is derived from the national accounts. However, the division between public and private investment is less straightforward. If we define public investment as the sum of investment by general government and by state enterprises, then we lack a standardized international database for such data. The Government Finance Statistics of the IMF has data only on general government (often omitting local governments) and not on state enterprises. We will utilize the GFS data in a subsequent section; in this section we use an imperfect but comprehensive measure of public investment including state enterprises. These data come from a combination of two sources: (1) the International Finance Corporation series on public and private investment through 1997; (2) the series on public investment in Easterly [1999]. The latter in turn was an amalgamation of data in Bruno and Easterly [1998] and Easterly and Rebelo [1993]. All of these sources use World Bank and IMF reports, and for a few countries, the United Nations National Accounts. In the absence of integrated accounts such mixed sources are the best we can assemble for aggregate data on public investment. After constructing a public investment/GDP series, we subtract it from national accounts' total investment/GDP to get private investment/GDP.

Figure 1 provides a first look at public investment/GDP and GDP growth in Africa. The graph does not provide much support for the view that public investment has a high payoff for growth. Most of the data are concentrated in clump in the lower half of the graph with no discernible association between growth and public investment. There are two outliers: Botswana (BWA) and Equatorial Guinea (GNQ) had exceptional growth but middle ratios of public investment. In contrast, Zambia, Comoros, Mozambique and Sao Tome had high public investment but limited growth. The only country with high public investment and substantial growth is Lesotho.

Figure 2 shows the corresponding graph for private investment/GDP and GDP growth. 
The figure shows some relation between private investment and growth although there are outliers like Congo (COG) and Gabon (GAB). The observation for Botswana suggests it will be influential in calculating the statistical association between private investment and growth - we will now confirm its impact. Table 1 presents the results of a cross-section regression for 197097 for 29 African countries. Private investment has a significant positive and strong effect on growth, even after attempting to control for its endogeneity. In contrast, public investment has no discernible effect on growth. The favorable impact of private investment on growth depends heavily on Botswana. The regression omitting Botswana is shown in Table 2.

The coefficient on private investment is only a third as large and no longer significant even significant at the 10 percent level. The variable that most explains relative growth performance now is population growth which has a negative impact. The regression excluding Botswana is enlightening as Botswana is atypical of the rest of Sub-Saharan Africa. Figure 3 shows that GDP per capita in SSA was roughly the same in 1998 as it was in 1960 whereas Botswana's had increased almost eight-fold. One source of this performance has been its pursuit of good policies including exceptionally able management of potential Dutch Disease given its enormous earnings from diamond exports. ${ }^{4}$ Yet unlike say Nigeria whose oil receipts also provided the potential for the achievement of rapid growth, Botswana was able to undertake policies that limited any adverse effects. As one measure of its generally responsible policies, budget deficits relative to GDP for Botswana and all of Africa are shown in Figure 4. Whereas Botswana has been in surplus, deficit levels have often risen above 10 percent in the rest of the continent. 5

Botswana's pro-market policies and lack of exchange controls on profit remittances also made it a "haven for foreign investors" in Africa. Yet at the same time, the government refrained from special subsidies for foreign investors intended to create "prestige projects" in the private sector. The government consistently made it clear it would protect private property rights. It was

\footnotetext{
${ }^{4}$ A good account of policy making in Botswana is given by Harvey and Lewis, 1990. For a discussion of the political and social factors that may have accounted for the quality of policy making see Acemoglu, Johnson, and Robinson, 2001.
} 
a "government of cattlemen" who were attuned to commercial interests (Harvey and Lewis 1990). A relatively low level of ethnic division inhibited the ethnically based rent-seeking common in the rest of Africa (Easterly and Levine 1997, Alesina et al. 2002). The relative political stability and relatively low corruption also made Botswana a favorable location for investment. Botswana's relatively high level of press freedom and democracy (continuing a precolonial tradition that held chiefs accountable to tribal members) held the government responsible for any economic policy mistakes. The government chose not to force the "indigenization" of the civil service, but retained many expatriate officials until the skill shortages at independence had been remedied (Acemoglu et al. 2001). All of these factors likely contributed to an efficient allocation of private investment across sectors.

What is our bottom line on the private investment regressions with and without Botswana? Botswana illustrates the potential payoff to private investment in Africa under a supportive political system and good institutions. Yet we are reluctant to make too much of a single data-point based on a very small and rather atypical economy. The poor growth return to private investment in the rest of Africa with the exception of Botswana seems to us to be the main story.

Another way to illustrate the small returns to investment in Africa is to show the predicted per capita income if there had been a linear relation between growth and investment in Africa. This is implemented for illustrative purposes rather than as a test of a specific growth model as the results are quite dramatic. Similar results are obtained for almost all individual countries. We predict growth using a simple linear model $\mathrm{g}=\mathrm{a} * \mathrm{I} / \mathrm{Y}-\mathrm{n}$, where $\mathrm{g}$ is per capita growth, $\mathrm{a}$ is the coefficient on investment, $\mathrm{I} / \mathrm{Y}$ is the investment ratio (a proxy for the growth of the capital stock given the long period considered), and $\mathrm{n}$ is the rate of population growth. We substitute in the actual values of I/Y and n, and choose the value of a so as to fit the early years of the period when investment was more productive than it became over time. We apply the predicted and actual per capita growth rates to derive a predicted and actual per capita income index, as shown in Figure 5. Figure 5 shows how the simple prediction for African per capita

\footnotetext{
${ }^{5}$ Botswana's unusual performance has also been noted in other cross-country studies, e.g., Auerbach et. al., 1993.
} 
income radically diverged from actual performance beginning in the mid-1970s. ${ }^{6}$ Investment rates indicated that per capita income growth should have continued in Africa rather than stagnating for a quarter century. We confirm this below when we explicitly consider growth in output per worker as a function of that in capital per worker rather than simply use investment as a proxy for capital stock. Figure 6 shows the predicted versus actual growth country by country. Virtually all of the countries lie below the $45 \%$ degree, indicating that predicted growth almost always exceeded actual growth. Moreover, a given actual growth rate corresponds to a wide variety of predicted growth rates, and vice versa. For example, both Uganda and Gabon had growth per capita between 2 and 3 percent per annum. Yet the linear investment growth model predicted that the former would grow at zero percent while the latter would grow at 8 percent! Another test of the relationship between investment and growth is to look at the relationship between the change in investment ratios and the change in growth per capita. One of the most famous predictions in development economics, dating back to Sir Arthur Lewis and Walt Rostow, is that increases in investment ratios lead to growth accelerations. Figure 7 shows this prediction fails to hold in Africa: there is no association between increases in investment in Africa and changes in growth from 1960-79 to 1980-99.

Does the low aggregate return to investment reflect low human capital in Africa? To test this association, we added the Barro-Lee years of schooling to the above regression, both as an independent term and as an interaction term with private investment. The effect of schooling was insignificant, confirming results by Pritchett [2001] that the educational expansion in Africa has so far not yielded a high payoff.

\section{B. Growth accounting}

Earlier we utilized the investment-output relation to broadly indicate the surprising lack of relation between the two in Africa despite widespread perception that a major source of low growth is the low level of investment. While investment/GDP ratios for such a long period are not a bad proxy for rates of growth of capital, we can also examine explicitly the relation 
between the capital-labor ratio and labor productivity, the conventional production function based approach. Figure 7 shows the observations for Africa of capital growth per worker and output growth per worker using data from Nehru and Dhareshwar [1993]. There is no statistically significant association between capital growth per worker and output growth per worker. The coefficient on capital growth per worker, which in the case of competitive factor and product markets should be the share of capital in output, is .21 and is significant only at the 15 percent level. The figure shows significant outliers such as Nigeria and Sudan, which had capital growth per worker of over 4 percent per annum, but had zero or negative growth of output per worker. Outliers in the other direction include Kenya and Mauritius, which had capital growth per worker of zero labor productivity growth of 2 percent per annum.

The relation between accumulation and growth is even weaker for a more recent period 1977-94 using data from Bruno and Easterly [1998]. ${ }^{7}$ Although 10 of the 19 countries with data had positive growth of capital per worker, only 3 had positive per capita output growth (Figure 9). The correlation between output growth and capital growth is once again insignificant. The $\mathrm{R}^{2}$ is only .10, indicating that capital growth per worker explains only 10 percent of the variation in growth of output per capita within Africa.

\section{Policies and Growth}

Given our concerns about the investment data, we next demonstrate that despite the small size of the sample and perhaps noisy data, a regression of per capita growth rates on policies works well for the Africa sample. The black market premium and the public sector balance have often been viewed as key macroeconomic indicators of the quality of public policy. The poor incentives created by foreign exchange market distortions and high budget deficits may explain why investment has not been productive in Africa. Thus, in Table 4 we present estimates of a pooled regression of four-year average per capita income growth rates 1970-92 for African

\footnotetext{
${ }^{6}$ Easterly 1999 gives a more general description of the failure of the linear growth-investment model.

${ }^{7}$ They used updated data through 1993 for capital stocks from Nehru and Dhareshwar and World Bank data through 1994 for output per capita.
} 
countries. The black market premium and the public sector balance/GDP are both significant with the expected sign. (The investment share is still insignificant when added to this regression.) These adverse policies may have more fundamental determinants such as the ethnic polarization discussed by Easterly and Levine (1997).

\section{Indirect evidence from aid and investment}

Another way to assess whether returns to capital were high or not is to calculate the response of investment to foreign aid. In discussions of foreign aid, it is often assumed that fixed investment in developing countries has good returns but it remains too low because of liquidity constraints and low domestic saving. Foreign aid that can alleviate both constraints should, under these assumptions, increase the growth rate. As has been demonstrated for a number of countries, increased aid may not result in additional investment due to the possibility of fungibility (Pack and Pack, 1993). This appears to be the case in Africa as well. Table 5 shows the results of regressing investment/GDP on overseas development assistance/GDP country by country for the period 1960-95. No country in Africa had a one for one pass-through of aid into investment, as would have been expected from the liquidity constraint idea. Eight out of 34 African countries had a significant and positive relationship between aid and investment; more (12) had a negative and significant relationship. There is no evidence from the aid-investment relationship of high returns to investment frustrated by lack of liquidity. ${ }^{8}$

What would have been the impact if investment had been productive and aid had in fact increased investment levels? Easterly [1999] performs such a calculation for Zambia. If all aid had gone into investment and investment had yielded an average payoff for growth (an ICOR of 3.5), then Zambia's per capita income by 1995 would have reached $\$ 20,320$; instead it declined to around $\$ 600$. The counterfactual of an income 34 times higher than actual demonstrates in a different manner that low investment was not the primary source of low African growth.

\footnotetext{
${ }^{8}$ This finding is in line with that of Boone [1995], who finds a zero coefficient across countries between aid (suitably instrumented) and investment.
} 


\section{E. Composition of public investment}

The finding that public investment is unproductive in Africa, which seems to be robust to various specifications and data sets, could be troubling to those who decried the cutbacks in government investment brought on by adjustment programs. Had these cutbacks been avoided, and public investment increased, our results show that Africa's growth in the periods considered would not have been any higher. A possible response would be that it is the composition, and not the level, of public investment that is important. Had African governments invested in health, education and infrastructure, for instance, the effects on per capita GDP growth would have been favorable. To test this hypothesis, we employ data from the IMF's Government Einance Statistics, which is the only internationally comparable database on the components of public expenditure. The total public investment figure is not consistent with that used in the previous regressions in this section. Nevertheless, the data from the GFS give qualitatively the same result for a regression of per capita GDP growth on private and public investment. When public expenditure more generally is broken down into its components, none of the individual expenditure items has a statistically significant association with growth. Furthermore, the coefficient on private investment is generally not statistically significant when controlling for

these different components of public expenditure. Given the levels of public spending in health, education, and infrastructure, additional private investment would not have benefited African growth. Finally, in assessing the determinants of private investment in Africa, we find that public investment has a negative coefficient--strengthening the possibility that there was more crowding out than crowding in.

\section{F. Implications}

The direct and indirect evidence of overall poor returns to investment in Africa in the cross-country data contradict the notion that investment was too low in Africa. Higher investment would not have had a high payoff. The much cited capital flight out of Africa may 
well have been a rational response to low returns at home. Collier et al [1999] find 39\% of African private wealth is held abroad. Indeed those Africans who changed their portfolios to foreign assets are probably better off than they would have been if they had invested solely at home.

\section{Evidence from Tanzanian manufacturing on the productivity of capital}

The absence of any aggregate investment-growth relationship reflects the evolution of productivity in many sectors in each country. Rather than analyze the investment-growth nexus across countries by sector we present evidence from Tanzanian manufacturing over time to obtain some insights into the source of the cross-country results presented in the previous section. ${ }^{9}$ Focusing on manufacturing in one country provides useful insights. In the simpler industrial activities that loom large in Tanzania, new technological developments are largely embodied in imported equipment, and relevant disembodied knowledge such as the proper organization of sets of equipment and quality control can be obtained from foreign consultants. Neither condition necessarily holds, for example, in agriculture where new technology in the form of appropriate seeds requires indigenous development (Evenson and Westphal, 1995). Thus, differences in national production functions that may affect cross- country results are less severe in manufacturing. It is also likely that both output and inputs are measured more accurately in the formal manufacturing for which Tanzanian data are available than in other sectors. Moreover, industrial production is relatively immune to natural forces such as drought or excessive rain that continue for several years and affect agricultural output. ${ }^{10}$

Value added per worker, $v=V A / N$, in Tanzania fell between 1975 and 1990 for the entire manufacturing sector and its component branches (Table 5). There are two potential sources of the decline, depicted in Figure 10.

\footnotetext{
${ }^{9}$ We believe an in-depth intertemporal case study is useful in obtaining an understanding of some of the aggregate results. But even if one wanted to undertake cross-country analysis at the sectoral level, this is very difficult as few African countries have data on investment by sector.

${ }^{10}$ Of course, the decline in rural demand resulting from natural calamities may reduce the demand for manufactured products and result in excess capacity unless production is internationally competitive and can be switched to export markets.
} 
1. A decrease in the capital-labor ratio along the 1975 production function - a move from A to B could have led to the observed decline in v. Such a movement might be attributable to: (a) a decline in the wage-rental ratio, w/P, leading firms to reduce their capital-labor ratios, $\mathrm{k}$, implying a decline in $\mathrm{v}$ unless TFP increased; (b) the hiring of unnecessary labor, particularly in public enterprises acting as employers of last resort; (c) a reduction in the flow of capital services (from the diminished capital stock) as capacity utilization declines due either to fall in demand or to the unavailability of complementary inputs, the latter due to foreign exchange constraints in the aggregate economy that forces firms to decrease production even where there is a potential for profitable sales. Ndulu (1986) also considers the possibility that output growth has not matched capacity growth due to a decline in utilization rates.

2. A decline in TFP, a movement from A, the position in 1975, to C or D in 1990, implying technological forgetting or an increase in the weight of low productivity sectors or firms, particularly public enterprises.

\section{A. Changes in Capital per Worker and Incentives to alter the capital-labor ratio}

Table 6 shows the nominal wage in Tanzanian manufacturing along with the major components of the user cost of capital, the price indices for non-residential structures and equipment. The expression for the user cost of capital, ignoring any capital gains, is

$$
\left.\mathrm{P}_{\mathrm{K}}=\mathrm{C}_{\mathrm{K}}\left[\left(\mathrm{i}-\mathrm{p}^{*}\right)+\mathrm{d}\right)\right]
$$

where $P_{K}$ is the user cost of capital, $C_{K}$ is the price of new capital goods, $i$ is the nominal rate of interest, $\mathrm{p}^{*}$ is the growth rate of the general price index, and $\mathrm{d}$ the depreciation rate. A major component of $\mathrm{P}_{\mathrm{K}}$ is the cost of investment which rose very rapidly. The appropriate value of (i$\mathrm{p}^{*}$ ) is difficult to determine empirically. Although $\mathrm{p}^{*}$ can be calculated from official statistics, the correct value of the nominal interest rate that firms could earn is not clear. We assume that firms have the alternative of lending in the gray market at a fixed percentage above the rate of 
inflation and therefore this remained constant. Unless the "true" value declined very rapidly, $\mathrm{W} / \mathrm{P}_{\mathrm{K}}$ would still have declined.

Tanzania experienced a significant decline in the wage-rental ratio, $\mathrm{w} / \mathrm{P}_{\mathrm{K}}$ during the period 1975-90. The user cost of capital rose as the local price of imported equipment increased due to devaluations. Local construction costs went up as well. The optimal capital-labor ratio should thus have declined leading to a decrease in labor productivity unless this was offset by a rise in TFP. Surprisingly, as we shall see, Tanzanian data imply that k for the entire sector grew, substantially in some periods, despite the decline in the wage-rental ratio. Such movements could have been due to a shift in the composition of output towards sectors with greater $\mathrm{k}$ but sector specific capital-labor ratios are not available to allow a test of this.

For three of the four sub-periods, the wage-rental ratio was unambiguously decreasing, the price deflator for both investment components increasing more rapidly than wages. Only in 1980 to 1985 would the movement in $\mathrm{w} / \mathrm{P}_{\mathrm{K}}$ depend on the particular function used to aggregate the price indices. This indicates that optimal k should have been declining which would imply a decrease in $\mathrm{v}$ unless there was an offsetting growth in TFP. Yet the data indicate that $\mathrm{k}$ was increasing through most of the period for the entire sector. Van Engelen [1996, p. 55] presents the annual investment/value added, I/VA, ratio in Tanzanian manufacturing for the period 1966 to 1994 based on government data. We have calculated averages for consecutive five year periods, shown in Table 7. The values in several periods are quite surprising, e.g., in 1986-90 investment exceeded value added originating in manufacturing and in 1977-1979 the ratio was close to unity. The I/VA rates can be converted into gross capital stock growth rates by noting that $\mathrm{K}^{*}=(\mathrm{I} / \mathrm{VA}) /(\mathrm{K} / \mathrm{VA})=\mathrm{i} / \theta$ where $\theta$ is the marginal capital-output ratio. Subtracting the depreciation rate, $d$, yields the growth rate of net capital stock, $K_{n} *=K^{*}-d$. This exercise is carried out in Table 7 using two values for $\theta$ and $\mathrm{d}^{11}$

\footnotetext{
${ }^{11} \mathrm{We}$ are not using the measured values of $\theta$ which are themselves endogenous and reflect inefficiency in the use of capital. Rather, the values used, 3 and 6, reflect the boundaries of experience in relatively efficient economies over time. In Tanzania, the ICOR was roughly 3 during the 1967-74 period (World Bank, 1977). Insofar as $\theta$ is greater and the actual growth of the capital stock is lower than that recorded, the low growth of $\mathrm{K}^{*}$ is not due to the lack of investment but to inefficiency. Note that if cost minimizing behavior prevailed, the optimal output capital ratio,
} 
Even making the assumptions least favorable to finding a substantial value of $\mathrm{K}, \theta=6$ and $d=.05$, the growth rate of the capital stock was positive over the fifteen years (column 7). For $\theta=3$ and $\mathrm{d}=.05$, the capital stock growth rate would have exceeded 17 percent over the period (column 4), much greater than that of the growth of the labor force shown in column 3. For the period 1976 to 1990, Tanzanian manufacturing's capital-labor ratio grew substantially for all sets of assumptions yet the constant price value added per worker declined by about 40 percent! ${ }^{12}$ Capital-shallowing is not a plausible explanation of the observed decline in v. Indeed, in two periods of falling v, 1976-80 and 1981-85, the lowest implied growth rates of the capitallabor ratio are .034 and .112. Perhaps just as surprising is the continuing growth in the absolute size of the manufacturing labor force over the years despite stagnation or decline in constant price value added. Both phenomena together imply that firms were not minimizing costs, a result not surprising in an environment in which large numbers of government interventions assured that inefficient firms survived.

Using the assumptions yielding the lowest rate of growth of $\mathrm{k}, \theta=6$ and $\mathrm{d}=.05$, its average growth rate was about 8 percent per annum between 1976 and 1990. With $\alpha=.4$, this implies that $\mathrm{v}$ should have increased by 3.2 percent per year rather than decline by that amount. Using the relation $\mathrm{v}^{*}=\mathrm{A}^{*}+\alpha \mathrm{k}^{*}$, the value of $\mathrm{A}^{*}$ over the period is -6.4 . The absence of competitive pressures in product markets and policies to encourage firms to maintain employment for political purposes can perhaps explain low levels of both $\mathrm{v}$ and TFP. But the continuing decline of the latter over fifteen years is surprising. A pattern such as this appears to be fairly widespread throughout Africa and is one of the sources of the lack of association between investment and growth in per capita income reported in the preceding section.

\section{B. Explanations of the Decline in Productivity}

A number of hypotheses about the factors that could explain the combination of a rapidly

$(\mathrm{VA} / \mathrm{K})^{*}=\left[(\alpha / 1-\alpha)\left(\mathrm{w} / \mathrm{P}_{\mathrm{K}}\right)\right]^{\alpha-1}$ using the Cobb-Douglas. With $\mathrm{w} / \mathrm{P}_{\mathrm{K}}$ declining, $\theta=\mathrm{K} / \mathrm{Q}$ as well as $\mathrm{k}$ should have declined and the value of $\mathrm{K}^{*}$ for a given investment rate should have increased.

${ }^{12}$ See Table 5. 
growing capital-labor ratio and declining labor productivity have been considered. Several were noted above in motivating Figure 10. Two sets of causes can be cited that reduce labor productivity, broadly re-allocative and efficiency reducing. Among the former, the reallocation of labor from high to lower (labor) productivity sectors within manufacturing is a plausible candidate. However, calculations of the change in productivity due to reallocation of labor among manufacturing branches with differing $\mathrm{v}$ turns up a miniscule effect in explaining the large decline v between 1975 and 1990. Similarly, estimates of the productivity losses from the expansion of Tanzania's state owned manufacturing enterprises suggests this was not the major source of the decline in manufacturing wide v. Indeed, it is not clear that the SOE sector has lower TFP levels than the private sector, perhaps as a result of its favored access to imported inputs and the resulting higher rates of capacity utilization. ${ }^{13}$

A change in the rate of capacity utilization is one candidate. It is known that throughout much of sub-Saharan Africa factories operate one shift at most and there is a perception that the rate of utilization has gone down due to a shortage of imported inputs upon which local industry depends. The evidence available in Tanzania suggests a decline of about 3.2 percent a year between 1976 and 1990. If the underlying production function were Cobb-Douglas with $\alpha=.4$, about $1.3 \%$ of the annual decline of 6.4 could be explained.

The full set of determinants of the decline in Tanzanian labor productivity cannot be found. There are some anecdotal clues, particularly the abandonment of some major enterprises which may go some way in explaining the result. To return to our broad theme, however, it is clear that the relation between growth of per capita income and investment may be tenuous in the one sector in which we would expect the most stable relation, as it is unaffected by phenomena such as variable weather. Until the sources of declining productivity are better understood, advocacy of more investment as a source of growth is premature.

\section{Conclusions}

\footnotetext{
${ }^{13}$ Kweka and Morrisey (2000) find that government investment, some of it in publicly owned enterprises, reduces aggregate growth rates. Insofar as TFP levels were declining in both the public and private sectors, public investment would have contributed to the decrease in output per worker.
} 
Our goal in this paper has been the analysis of the claim that Africa's weak growth performance is due to low investment rates. The cross-country evidence suggests that there is no direct relationship. A positive and significant coefficient on private investment is driven by the presence of Botswana in the sample - omitting Botswana eliminates the finding. Allowing for the endogeneity of private investment, controlling for policy, and positing a nonlinear relationship makes no difference to the conclusion. Higher investment in Africa would not by itself produce faster GDP growth. Africa's low investment and growth rates therefore, seem to be symptoms of underlying factors.

To investigate these factors, and to correct for some of the problems with cross-country analysis, we undertook a case study of manufacturing investment in Tanzania. We attempted to identify the reasons why output per worker declined while capital per worker increased. Some of the usual suspects, such as shifts from high to low productivity subsectors, the presence of state-owned enterprises, or poor policies, did not play a significant role in this decline. Decreasing capacity utilization (possibly the by-product of poor policies) explains about 1/6 of the decline in TFP but the source of the rest of the decline is not easily explained. If Tanzania is not atypical of Africa, the low productivity of investment was not due to any single factor, but to a combination of factors, all of which occurred simultaneously.

What are the implications of these results? First, analysts and policy makers should be more careful about calling for an investment boom to obtain a resumption of growth in Africa. Unless some or all of the underlying factors that made investment unproductive in the past are addressed, the results may be disappointing. We should also be more circumspect about Africa's low savings rate. Perhaps the low savings rate was due to the fact that the returns to investment were so low. And the relatively high level of capital flight from Africa may have been a rational response to the lack of investment opportunities at home.

Secondly, our results suggest that there is no single key to unlocking investment and GDP growth in Africa. Just as a combination of factors contributed to investment's low 
productivity in the past, the solution lies in addressing this set of factors simultaneously.

\section{References}

Acemoglu, Daron, Simon Johnson, and James A. Robinson, “An African Success Story: Botswana," Working Paper 01-37, Department of Economics, Massachusetts Institute of Technology.

Alesina, Alberto, Arnaud Devleeschauwer, William Easterly, Sergio Kurlat, and Romain Wacziarg, "Fractionalization", mimeo, June 2002.

Auerbach, Alan J; Hassett, Kevin A; Oliner, Stephen D., (1994) Reassessing the Social Returns to Equipment Investment. The Quarterly Journal of Economics. 109: 789-802.

Barro, Robert J. and Jong-Wha Lee. 1994. "Losers and Winners in Economic Growth," in Proceedings of the Annual World Bank Conference on Development Economics, 1993, pp. 26797.

Bruno, Michael and William Easterly, "Inflation Crises and Long-run Growth," Journal of Monetary Economics, February 1998.

Calamitsis, Evangelos, Anupam Basu, and Dhaneshwar Ghura, "Adjustment and Growth in SubSaharan Africa," International Monetary Fund Working Paper 99/51.

Collier, Paul and Jan Willem Gunning, 1999, "Explaining African Economic Performance," Journal of Economic Literature, 37:1, pp. 64-111.

Collier, Paul, Anke Hoeffler, and Catherine Patillo, February 1999, "Flight Capital as a Portfolio Choice," World Bank Policy Research Paper 2066.

De Long, J. Bradford and Lawrence H. Summers. 1991. "Equipment Investment and Economic Growth," Quarterly Journal of Economics, 106:2, pp. 445-502.

Devarajan, Shantayanan, Vinaya Swaroop and Heng-fu Zou. 1996. "The Composition of Public Expenditures and Economic Growth," Journal of Monetary Economics, 37, pp. 313-44.

Easterly, William. "The Ghost of Financing Gap: Testing the Growth Model of the International Financial Institutions”, Journal of Development Economics, (60)2 December 1999 pp. 423-438

Easterly, William and Ross Levine. 2001. "It's not factor accumulation: stylized facts and growth models," World Bank Economic Review.

Easterly, William and Ross Levine, “Africa's Growth Tragedy: Policies and Ethnic Divisions", Quarterly Journal of Economics, November 1997. 
Easterly, William and Sergio Rebelo. 1993. "Fiscal Policy and Economic Growth,” Journal of Monetary Economics, 32:3, pp. 417-58.

Elbadawi, Ibrahim A., Benno J. Ndulu and Njuguna Ndung'u. 1998. "Risks, Uncertainties and Debt Overhang as Determinants of Private Investment in Sub-Saharan Africa," mimeo.

Evenson, Robert E. and Larry E. Westphal, 1995, “Technological Change and Technology Strategy"in Jere Behrman and T.N. Srinivasan, eds., Handbook of Development Economics 3a, Amsterdam, North Holland.

Ghura, Dhaneshwar and Michael T. Hadjimichael. 1996. "Growth in Sub-Saharan Africa." IMF Staff papers. Washington, D.C.: International Monetary Fund.

Grenier, Louise, Andrew McKay, and Oliver Morrissey, 1999, "Competition and Business Confidence in Manufacturing Enterprises in Tanzania,” CREDIT Research Paper, No. 99/2

Hadjimichael, Michael T., Dhaneshwar Ghura, Martin M $\eta$ hleisen, Roger Nord and E. Murat UHer. 1995. "Sub-Saharan Africa, Growth, Savings, and Investment, 1986-93." Washington, D.C.: International Monetary Fund.

Hadjimichael, Michael T. and Dhaneshwar Ghura. 1995. "Public Policies and Private Savings and Investment in Sub-Saharan Africa: An Empirical Investigation.” IMF Working paper. Washington, D.C.: International Monetary Fund.

Harvey, Charles and Stephen Lewis, Jr. (1990), Policy Choice and Development Performance in Botswana, New York, St. Martins Press.

Hoeffler, Anke. 1999. "The Augmented Solow Model and the African Growth Debate," Centre for the Study of African Economies, Oxford University.

Khan, Mohsin S and Manmohan S. Kumar. 1997. "Public and Private Investment and the Growth Process in Developing Countries," Oxford Bulletin of Economics and Statistics, 59, 1. Oxford: Blackwell Publishers Ltd.

Khan, Mohsin S. and Carmen M. Reinhart. 1990. "Private Investment and Economic Growth in Developing Countries,” World Development, Vol. 18. No.1 pp.19-27.

Klenow, Peter J. and Rodriguez-Clare, Andres. (1997b) "The Neoclassical Revival in Growth Economics: Has it gone too Far?" NBER Macroeconomics Annual (MIT Press), pp. 73-114.

Kweka, J.P. and O. Morrisey, 2000, "Government Spending and Economic Growth in Tanzania, 1965-96” CREDIT Research Paper. No 99/2, University of Nottingham.

Levine, Ross and David Renelt. "A Sensitivity Analysis of Cross-Country Growth Regressions," American Economic Review, 82:4, pp. 942-63. 
Mlambo, Kupkile and Adam B. Elhiraika. 1997. "Macroeconomic Policies and Private Saving and Investment in SADC Countries," Economic Research Papers, No. 33. Cote d'Ivoire: The African Development Bank.

Nelson, Richard R. and Howard Pack. 1999. "The Asian Growth Miracle and Modern Growth Theory," Economic Journal, 109:416-436.

B.J. Ndulu, 1986, "Investment, Output Growth and Capacity Utilization in an African Economy:The Case of Manufacturing Sector in Tanzania," Eastern African Economic Review 2:14-30.

Oshikoya, T. W. 1992. "Interest Rate Liberalization, Savings, Investment and Growth: The Case of Kenya," in Savings and Development, No. 3.

Oshikoya, Temitope W. 1992. "Macroeconomic Adjustment, Uncertainty and Domestic Private Investment in Selected African Countries." $C \perp$ te d'Ivoire: The African Development Bank.

Oshikoya, Temitope W. 1994. "Macroeconomic Determinants of Domestic Private Investment in Africa: An Empirical Analysis," in Economic Development and Cultural Change. The University of Chicago.

Pack, Howard and Janet Rothenberg Pack, 1993, "Foreign Aid and the Question of Fungibility," Review of Economics and Statistics, 1993. 258-65.

Pack, Howard, (1994) "Endogenous Growth Theory: Intellectual Appeal and Empirical Shortcomings," Journal of Economic Perspectives, 8:55-72.

Parente, Stephen and Edward Prescott, 2000, Barriers to Riches, Cambridge, MIT Press.

Prins I.M. and Adam. Szirmai, 1998, “A Reconstruction of Manufacturing Statistics,” Department of Technology and Development Studies, Faculty of Technology Manaagement, Eindhoven University of Technology.

Pritchett, Lant (2001) "Where Has All the Education Gone?" World Bank Economic Review, 15:367-91.

Sachs, Jeffrey and Andrew M. Warner. 1997. "Sources of Slow Growth in African Economies," Journal of African Economies, 6, pp. 335-76.

Van Engelen D.M., 1996, Public Policy Making and the Rise and Fall of the Tanzanian Manufacturing Sector. M.Sc. thesis, Faculty of Technology Management, Eindhoven University of Technology, Eindhoven, Netherlands. 
Young, Alwyn. (1995) "The Tyranny of Numbers: Confronting the Statistical Realities of the East Asian Growth Experience," Quarterly Journal of Economics, 110, pp. 641-680. 


\section{Table 1}

\begin{tabular}{|c|c|c|c|c|}
\hline \multicolumn{5}{|c|}{$\begin{array}{l}\text { Dependent Variable: GROWTH OF INCOME PER CAPIT } \\
\text { Method: Two-Stage Least Squares } \\
\text { Included observations: } 29 \\
\text { Excluded observations: } 17 \text { after adjusting endp } \\
\text { Instrument list: C PRVINV70 PUBINV POPGROW RGDPCH70 }\end{array}$} \\
\hline Variable & Coefficient & Std. Error & t-Statistic & Prob. \\
\hline $\begin{array}{l}\text { CONSTANT TERM } \\
\text { PRIVATE } \\
\text { INVESTMENT/GDP }\end{array}$ & $\begin{array}{l}0.000692 \\
0.375311\end{array}$ & $\begin{array}{l}0.020264 \\
0.113537\end{array}$ & $\begin{array}{l}0.034135 \\
3.305626\end{array}$ & $\begin{array}{l}0.9731 \\
0.0030\end{array}$ \\
\hline $\begin{array}{l}\text { PUBLIC } \\
\text { INVESTMENT/GDP }\end{array}$ & -0.025896 & 0.125628 & -0.206132 & 0.8384 \\
\hline $\begin{array}{l}\text { POPULATION } \\
\text { GROWTH }\end{array}$ & -0.943977 & 0.655257 & -1.440622 & 0.1626 \\
\hline $\begin{array}{l}\text { INITIAL INCOME } \\
1970\end{array}$ & $-9.62 E-06$ & 5.15E-06 & -1.867287 & 0.0741 \\
\hline $\begin{array}{l}\text { R-squared } \\
\text { Adjusted R-squared } \\
\text { S.E. of regression } \\
\text { F-statistic } \\
\text { Prob(F-statistic) }\end{array}$ & $\begin{array}{l}0.503848 \\
0.421156 \\
0.015651 \\
5.558181 \\
0.002593\end{array}$ & $\begin{array}{l}\text { Mean de } \\
\text { S.D. dep } \\
\text { Sum squ }\end{array}$ & $\begin{array}{l}\text { endent var } \\
\text { endent var } \\
\text { ared resid }\end{array}$ & $\begin{array}{l}0.004151 \\
0.020571 \\
0.005879\end{array}$ \\
\hline
\end{tabular}


Table 2

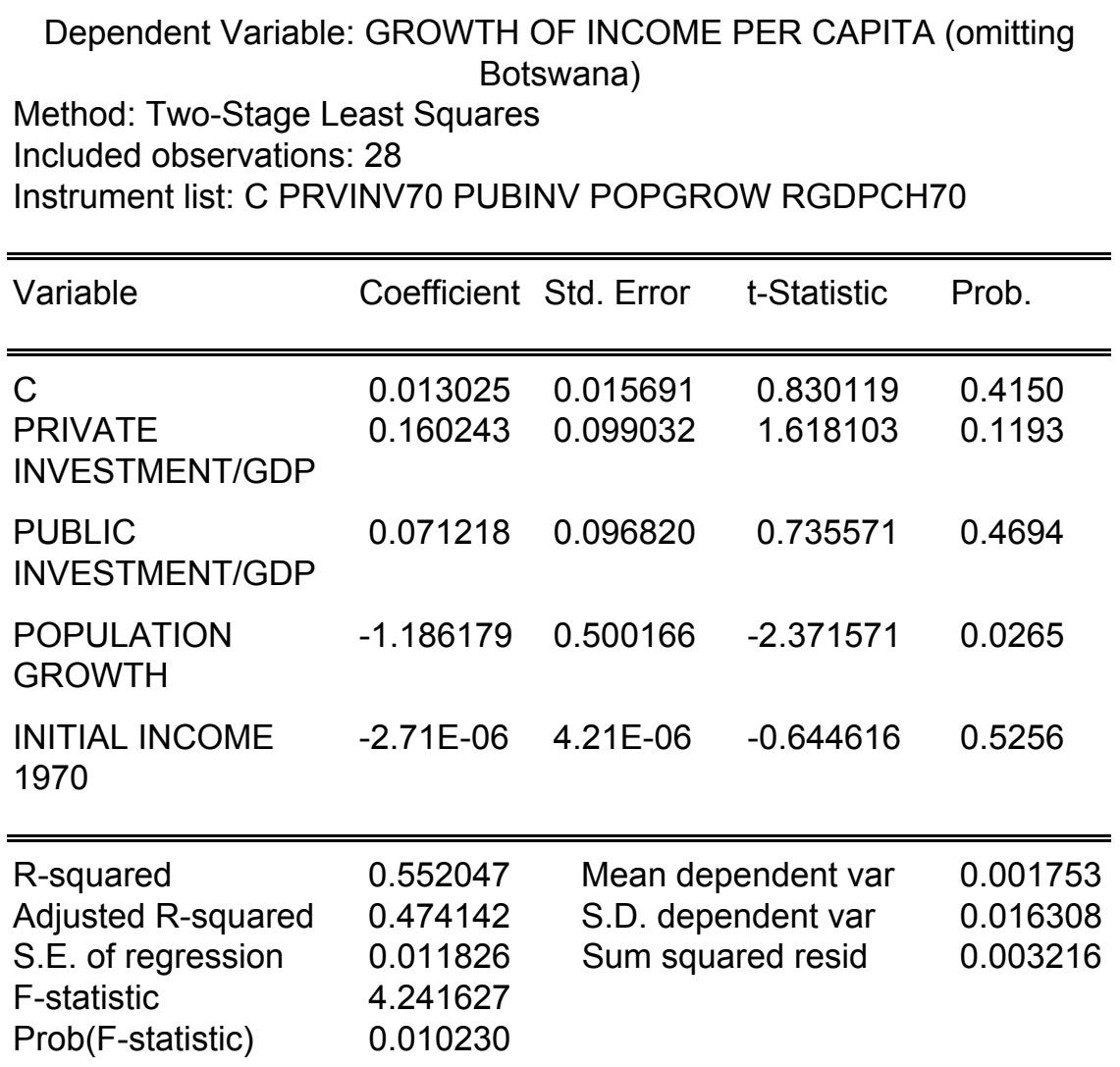


Table 3

Dependent Variable: GROWTH OF INCOME PER CAPITA

Method: Least Squares

Africa Sample only, 4 year averages, 1970-92

Included observations: 94

White Heteroskedasticity-Consistent Standard Errors \& Covariance

\begin{tabular}{lrrrr}
\hline \hline Variable & Coefficient & Std. Error & t-Statistic & Prob. \\
& & & & \\
\hline \hline C & 0.012106 & 0.004455 & 2.717516 & 0.0079 \\
Black Market Premium & -0.004747 & 0.002381 & -1.993464 & 0.0492 \\
Pub. Sec Balance/GDP & 0.002702 & 0.000602 & 4.487297 & 0.0000 \\
& & & & \\
\hline \hline R-squared & 0.178598 & Mean dependent var & -0.005259 \\
Adjusted R-squared & 0.160546 & S.D. dependent var & 0.032664 \\
S.E. of regression & 0.029928 & Akaike info criterion & -4.148670 \\
Sum squared resid & 0.081506 & Schwarz criterion & -4.067501 \\
Log likelihood & 197.9875 & F-statistic & 9.893117 \\
& & Prob(F-statistic) & 0.000130 \\
& $=\overline{ }$ & & \\
\hline \hline
\end{tabular}




\section{Table 4}

\section{Results of regressing Gross Domestic Investment/GDP on ODA/GDP} country by country in Africa, 1965-95

\begin{tabular}{lll}
$\begin{array}{l}\text { Coefficient of Investment on } \\
\text { ODA }\end{array}$ & $\begin{array}{l}\text { Number of } \\
\text { countries }\end{array}$ & Percent of Sample \\
\hline Total & 34 & $100 \%$ \\
Positive, significant, and $>=1$ & 0 & $0 \%$ \\
Positive and significant & 8 & $24 \%$ \\
Positive & 17 & $50 \%$ \\
Negative & 17 & $50 \%$ \\
Negative and significant & 12 & $35 \%$
\end{tabular}




\section{Table 5}

Percentage Decline in Constant Price Value Added per Worker inTanzanian Manufacturing Sectors, 1975-90

\begin{tabular}{|l|c|}
\hline \multicolumn{1}{|c|}{ Sector } & $\begin{array}{c}\text { Percentage } \\
\text { Change }\end{array}$ \\
\hline Food, Beverages and Tobacco & -62 \\
\hline Textiles and Leather & -24 \\
\hline $\begin{array}{l}\text { Wood Products, Furniture, } \\
\text { Paper Products, Printing, } \\
\text { Publishing }\end{array}$ & -67 \\
\hline $\begin{array}{l}\text { Chemicals, Petroleum, } \\
\text { Rubber, Plastic Products }\end{array}$ & -22 \\
\hline Non-Metallic Minerals & -05 \\
\hline $\begin{array}{l}\text { Basic Metal Products, } \\
\text { Machinery \& Equipment, } \\
\text { Other Mfg. }\end{array}$ & -22 \\
\hline All Manufacturing & -39 \\
\hline
\end{tabular}

Source: I.M. Prins and A. Szirmai, 1998, Table 6.2. 


\section{Table 6}

Relative Factor Prices for Tanzanian Manufacturing

\begin{tabular}{|l|c|c|c|}
\hline Year & $\begin{array}{c}\text { Index of } \\
\text { Manufacturing } \\
\text { Wages }\end{array}$ & $\begin{array}{c}\text { Index of } \\
\text { Equipment } \\
\text { Prices }\end{array}$ & $\begin{array}{c}\text { Index of non- } \\
\text { residential } \\
\text { structures }\end{array}$ \\
\hline 1975 & 100 & 100 & 100 \\
\hline 1980 & 127 & 151 & 287 \\
\hline 1985 & 306 & 220 & 340 \\
\hline 1990 & 582 & 2421 & 1474 \\
\hline
\end{tabular}

Source: United Republic of Tanzania, Economic Survey, various issues; The World Bank, 1996. 
Table 7

\begin{tabular}{|c|c|c|c|c|c|c|c|}
\hline \multirow[t]{3}{*}{ Years } & Rate of & $\mathrm{I}_{\mathrm{M}} / \mathrm{GDP}_{\mathrm{M}}$ & & \multicolumn{4}{|c|}{ Rate of Growth of Capital Stock: } \\
\hline & (1) & (2) & (3) & (4) & (5) & (6) & (7) \\
\hline & & & & $\begin{array}{c}\theta=3 \\
d=.05\end{array}$ & $\begin{array}{c}\theta=3 \\
d=.03\end{array}$ & $\begin{array}{c}\theta=6 \\
d=.05\end{array}$ & $\begin{array}{c}\theta=6 \\
d=.03\end{array}$ \\
\hline $1971-75$ & .012 & 29.7 & .079 & .05 & .07 & .0 & .02 \\
\hline $1976-80$ & $\begin{array}{l}- \\
.071\end{array}$ & 79.9 & .066 & .22 & .24 & .08 & .10 \\
\hline $1981-85$ & -.008 & 65.0 & -.032 & .17 & .19 & .06 & .08 \\
\hline $1986-90$ & .010 & 106.8 & .027 & .31 & .33 & .13 & .15 \\
\hline
\end{tabular}

Sources: Column 1, calculated from Prins and Szirmai, cited above; Column 2, calculated from Van Engelen, 1996; Column 3, calculated from Prins and Szirmai, ibid. p. 40; Columns 4-7, calculations of author. 
Figure 1: Public investment/GDP and GDP Growth, 1970-97

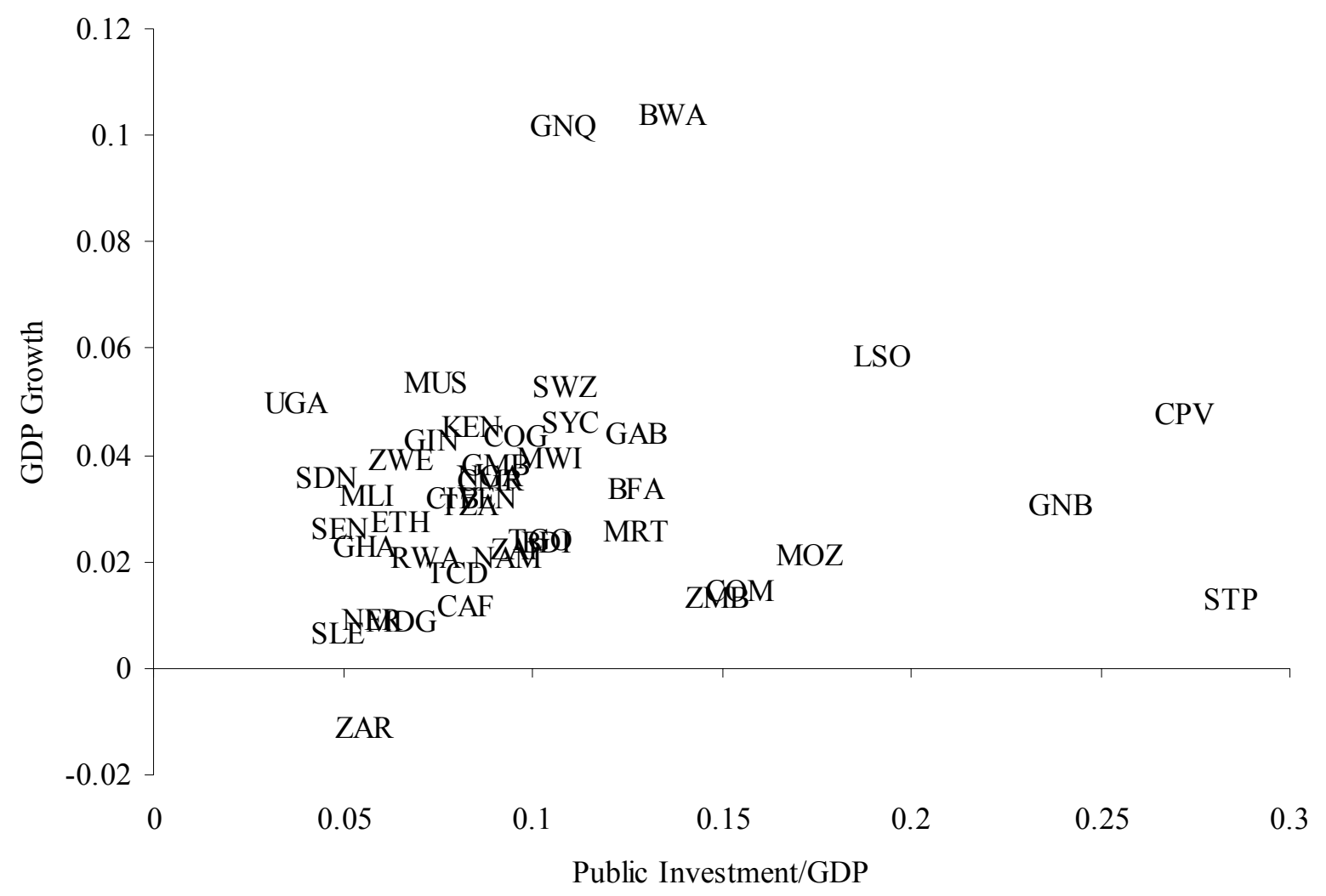


Figure 2: GDP Growth and Private Investment/GDP, averages 1970-97

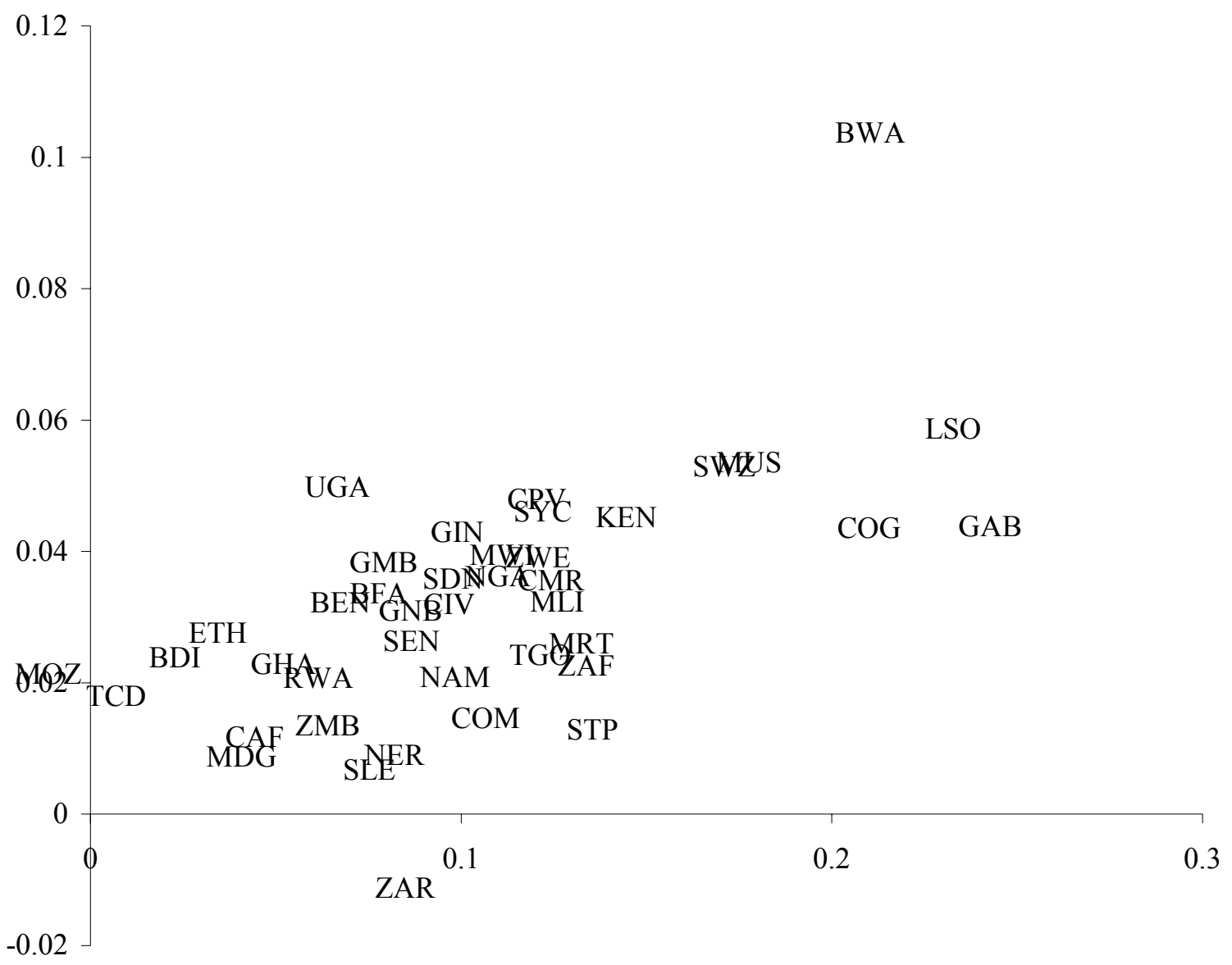


Figure 3

GDP per capita - Botswana and Sub-Saharan Africa

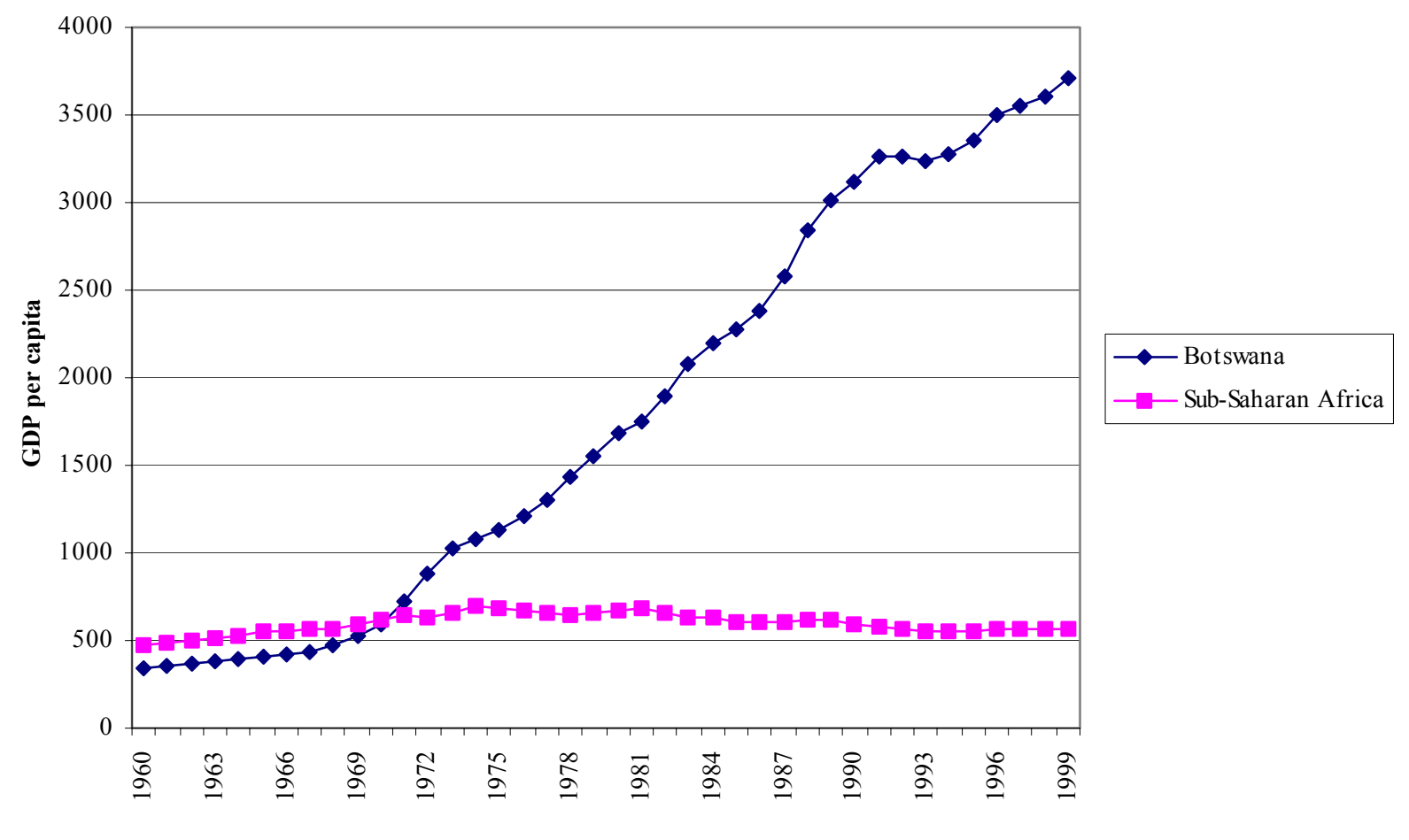


Fiugre 4

Budget Deficits as a Share of GDP - 1972-92

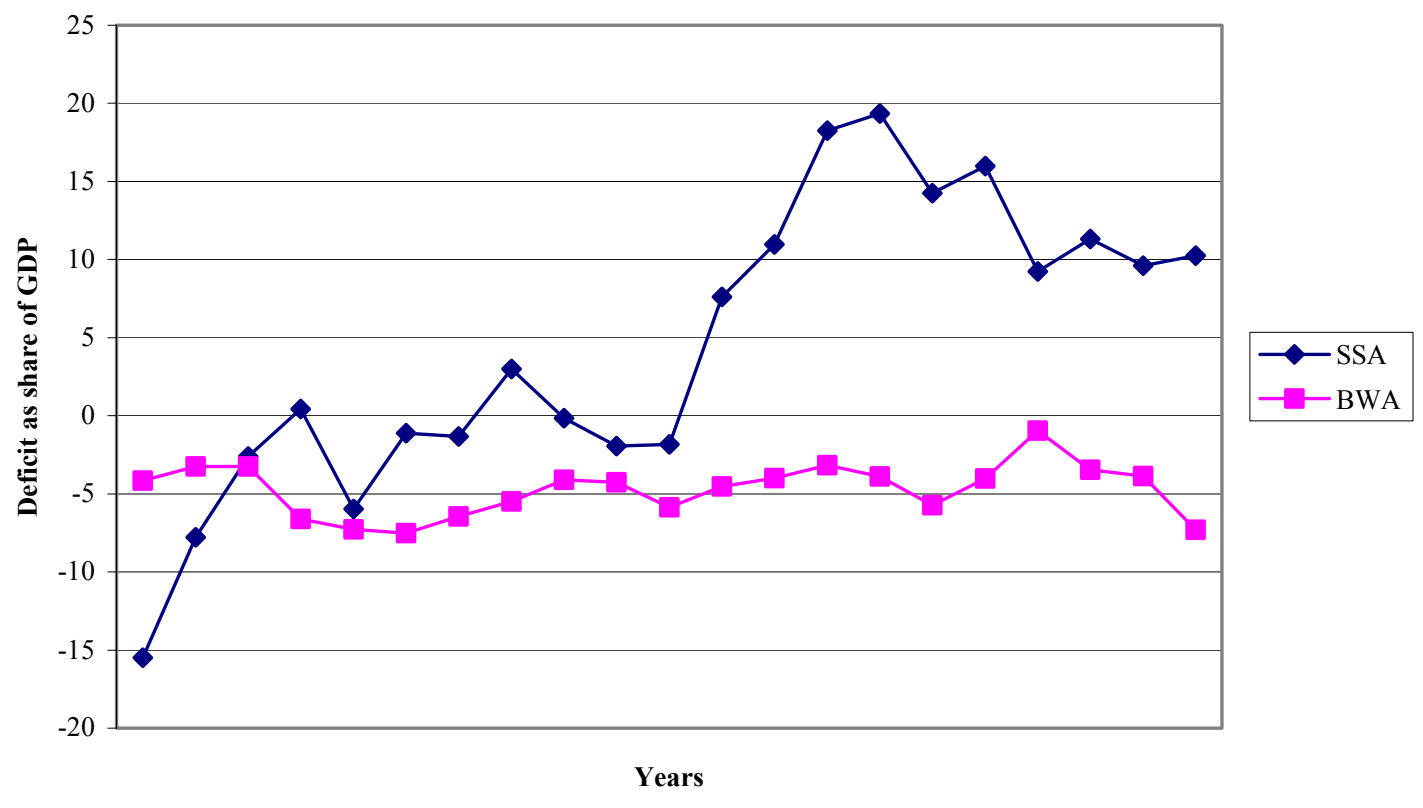




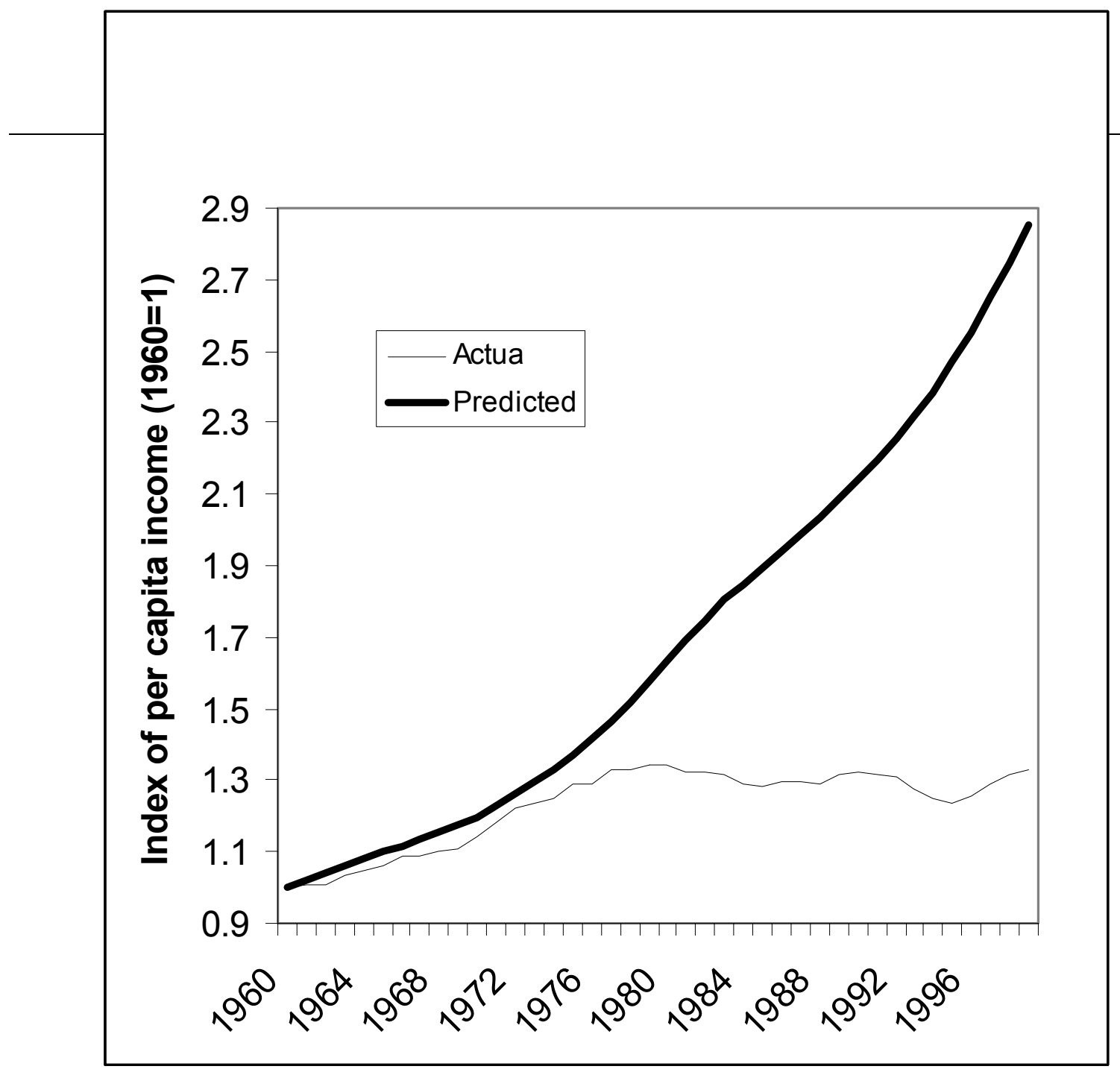




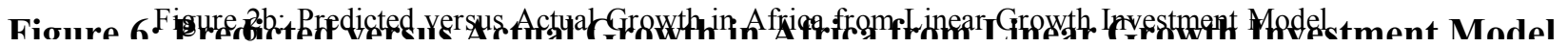

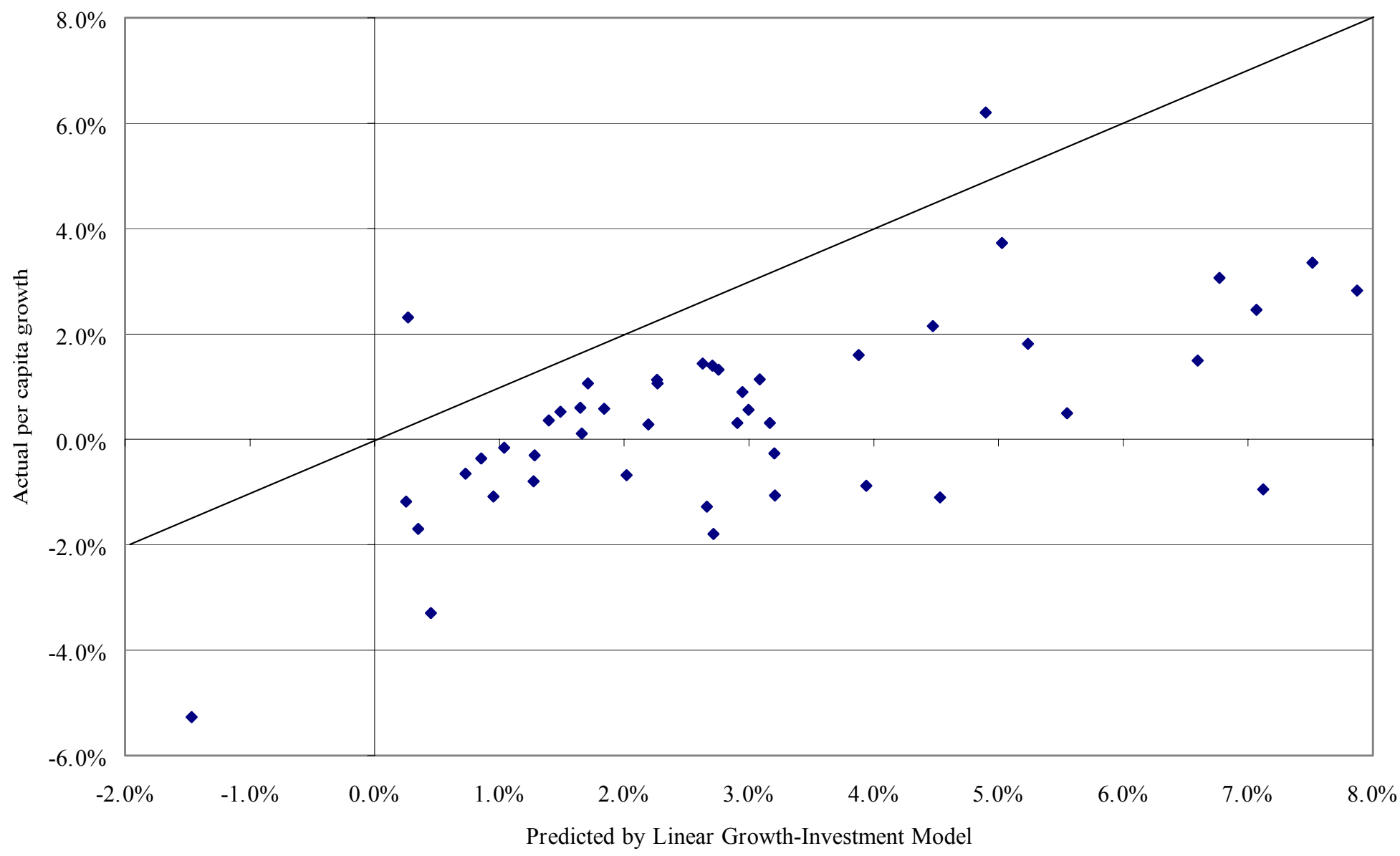




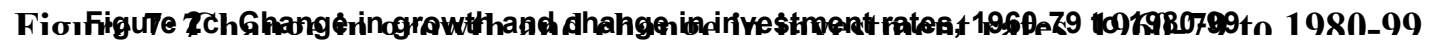

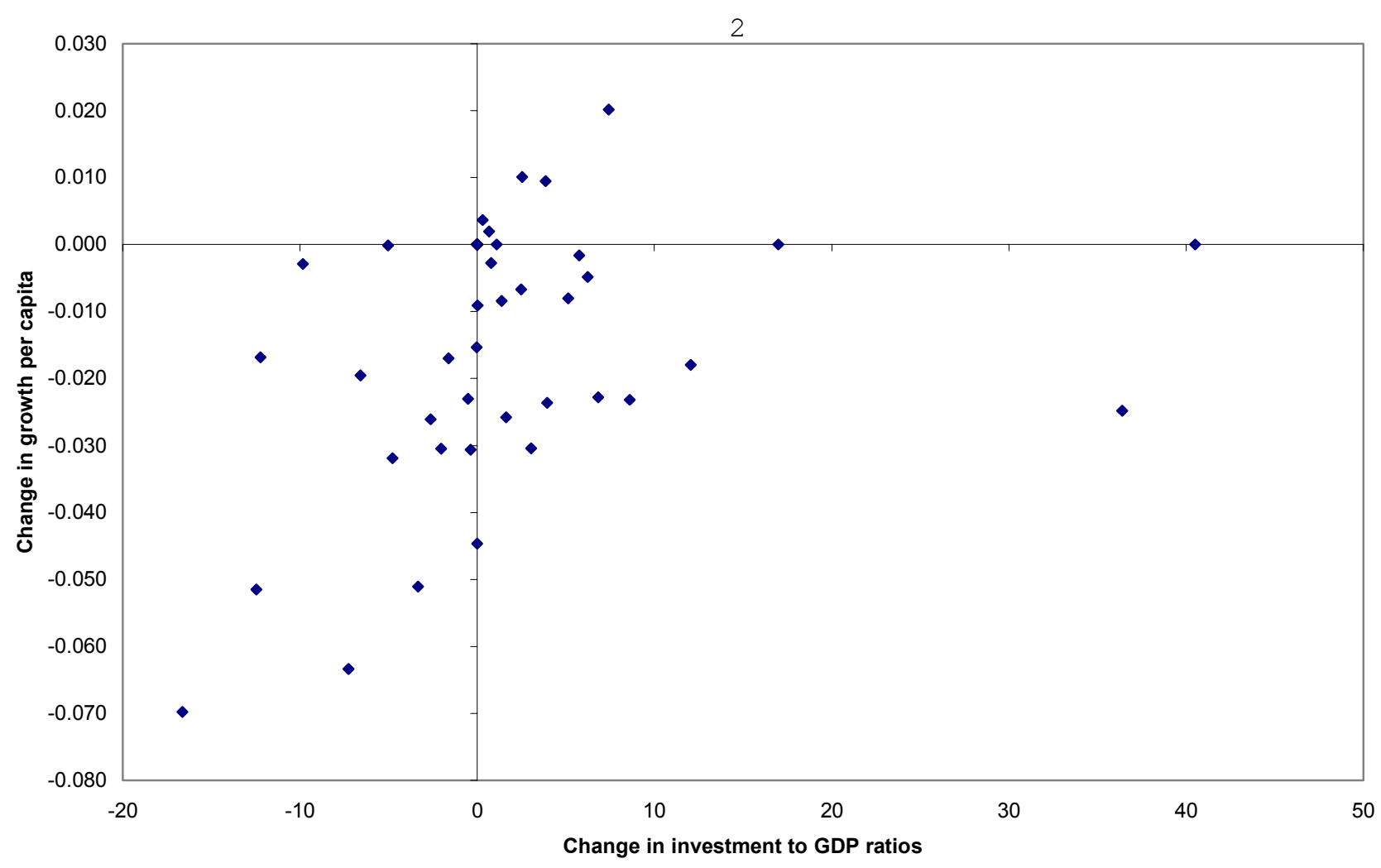


Figure 8: Output growth per worker against capital growth per worker, 1960-88

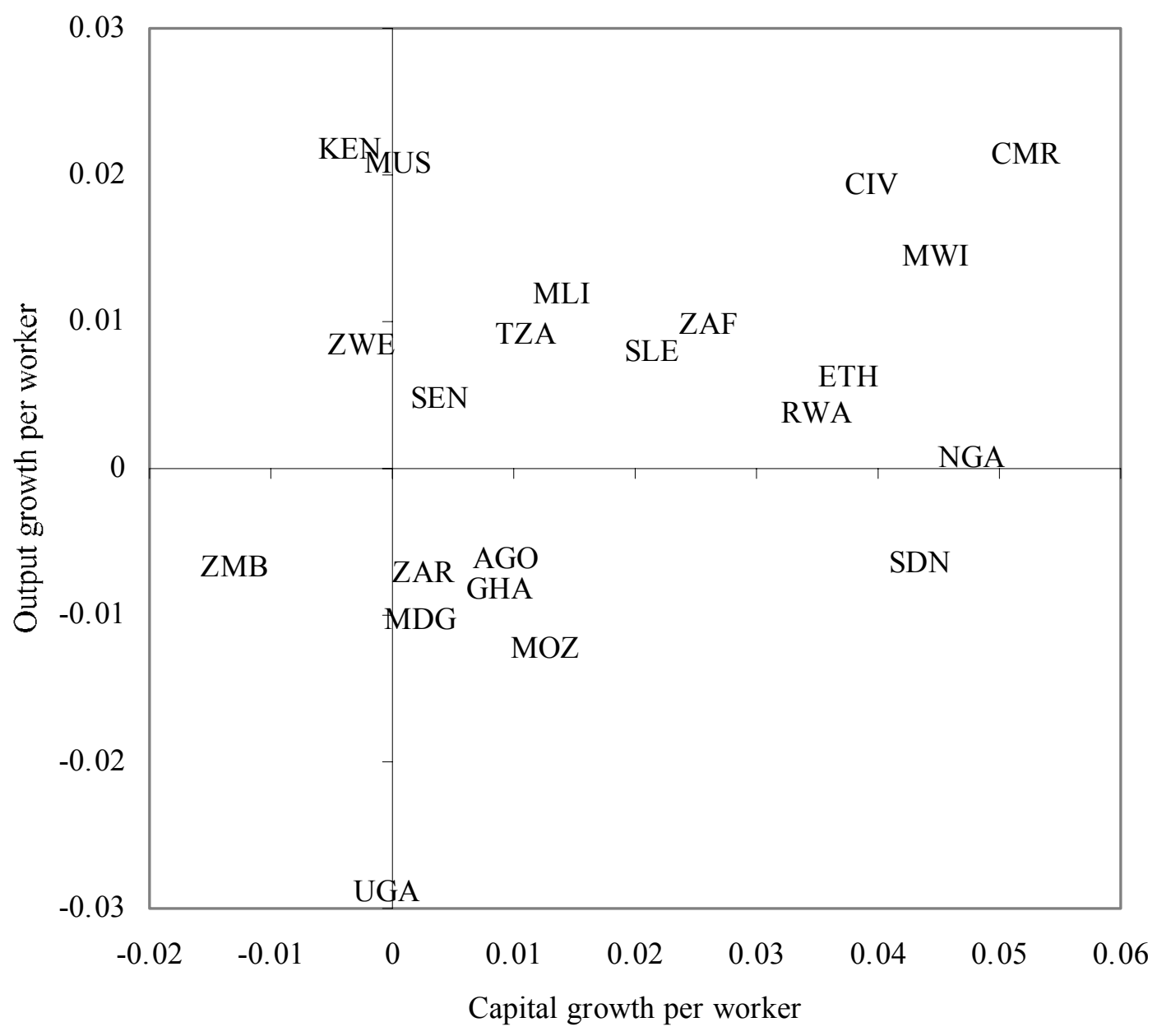


Figure 9

Output growth per worker against capital growth per worker, 1977.

94

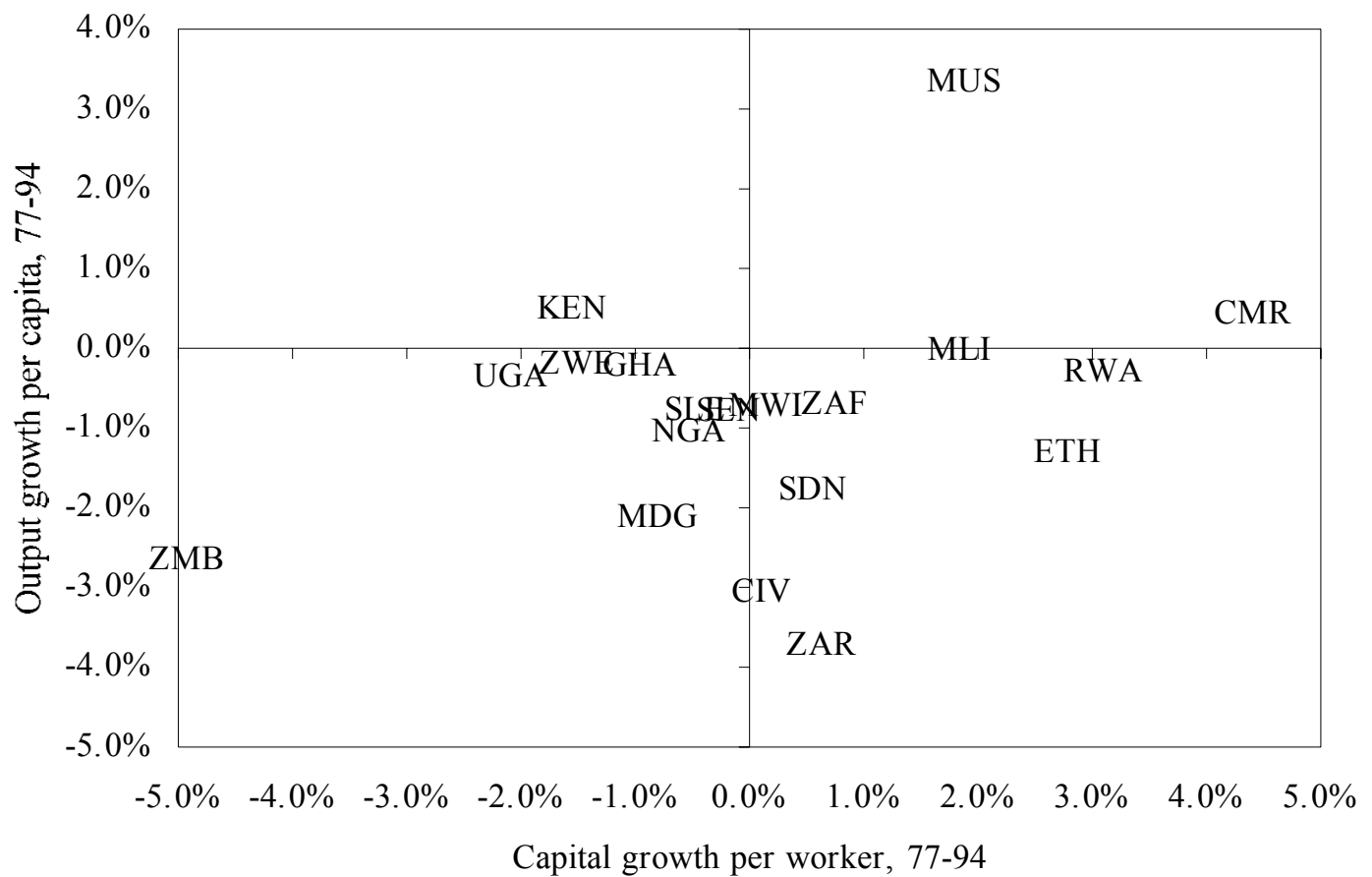


Figure 10

Possible Sources of Changes in Labor Productivity

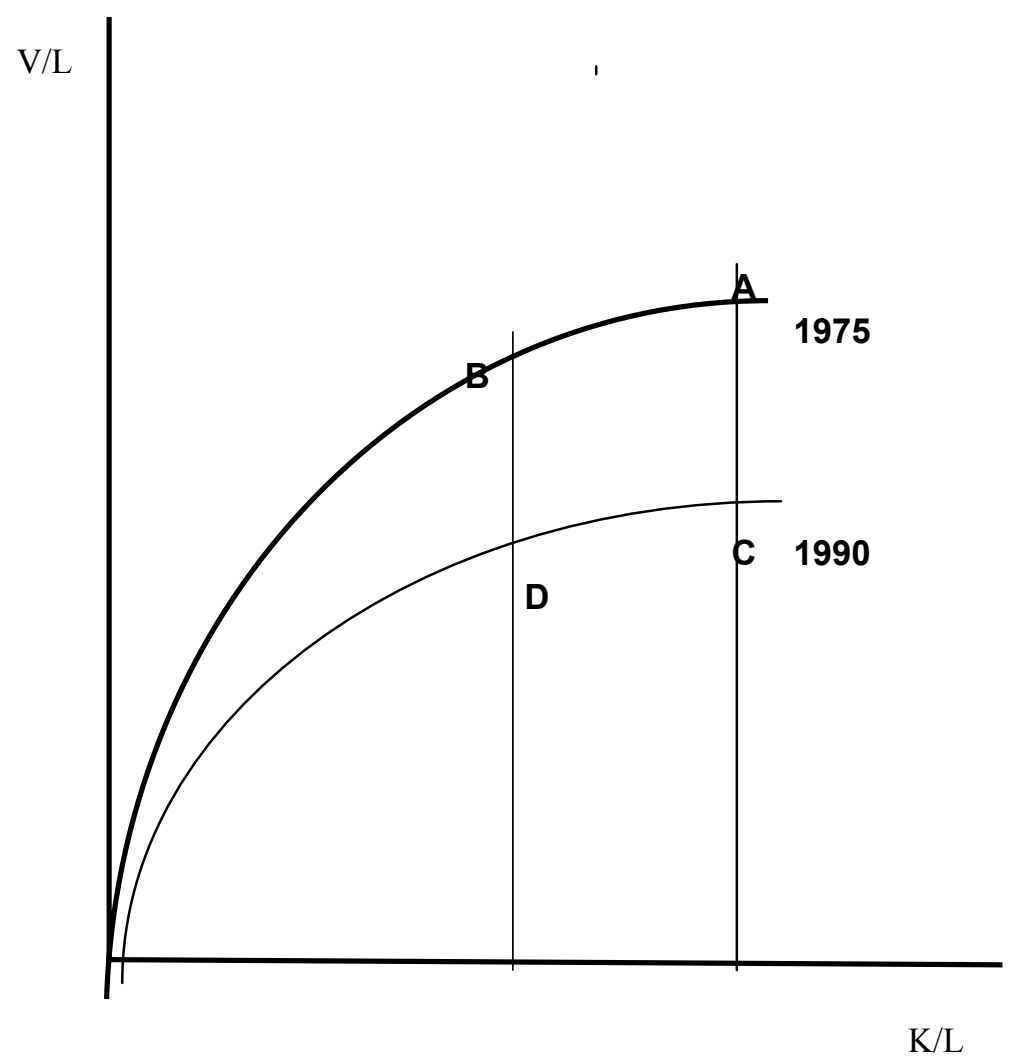




\section{Center for Global Development Working PAPers} AVAILABLE AT WWW.CGDEV.ORG

No. 1, January 2002

No. 2, January 2002

No. 3, February 2002

No. 4, March 2002

No. 5, April 2002

No. 6, May 2002

No. 7, May 2002

No. 8, June 2002

No. 9, August 2002

No. 10, September 2002

No. 11, October 2002

No. 12 , October 2002
Inequality Does Cause Underdevelopment: New Evidence. William Easterly

HIV/AIDS and the Accumulation and Utilization of Human Capital in Africa Amar Hamoudi and Nancy Birdsall

\section{External Advisors and Privatization in Transition Economies} John Nellis

The Cartel of Good Intentions: Bureaucracy versus Markets in Foreign Aid William Easterly

Intellectual Property and the Availability of Pharmaceuticals in Developing Countries Jean O. Lanjouw

Winners and Losers: Assessing the distributional impacts of privatization. John Nellis and Nancy Birdsall

Commodity Dependence, Trade, and Growth: When 'Openness' is Not Enough. Nancy Birdsall and Amar Hamoudi.

Financial Crises and Poverty in Emerging Market Economies. William Cline

An Identity Crisis? Testing IMF Financial Programming, William Easterly

Solutions when the Solution is the Problem: Arraying the Disarray in Development, Lant Pritchett and Michael Woolcock

What did structural adjustment adjust? The association of policies and growth with repeated IMF and World Bank adjustment loans.

William Easterly

Asymmetric Globalization: Global Markets Require Good Global Politics, Nancy Birdsall 